\title{
Intercultural Communication in Negotiation
}

\author{
(A Phenomenological Study on The Use of Sundanese Regional Language in The Process of \\ Banking Business Negotiations for FOs at Bank BTN)
}

\author{
Nurika Desy Marlinton*, Anne Maryani, O Hasbiansyah \\ Fakultas Ekonomi \\ Universitas Islam Bandung \\ Bandung, Indonesia \\ *desymarlintons@gmail.com, anmar2005@gmail.com, hasbians@yahoo.com
}

\begin{abstract}
A range of studies has examined how intercultural communication is in the negotiation process. Yet, no study to date has considered what happens when the negotiation cultural elements, namely the language, especially the Sundanese regional language which is in the realm of banking negotiations. Through a qualitative method with a phenomenological approach, it is described what an FO understands in his awareness and experience, it is found that the tendency to use Sundanese in the negotiation process as a form of an effort to get the emotional side of customers even though only uses simple language to attract attention, there are efforts to learn Sundanese to be able to understand what is conveyed by customers. Intercultural communication competence is deemed necessary as an adaptation process with interlocutors at least for social language to break the ice and reduce misunderstanding in the negotiation process.
\end{abstract}

Keywords-interculturar communication, negotiation, bank, language

\section{INTRODUCTION}

Communicating is needed not only for psychological needs but also for economic needs. The point is that when we carry out economic activities, communication is present in it. One of the existing economic activities is in the banking sector. One of the banking activities is collecting funds from the public. The activity of raising funds is called funding.

The matter regarding raising these funds has been stated in SEOJK Number 12 / SEOJK.07 / 2014 [1], even to the communication process like what is carried out in raising these funds. One of the points mentioned in the points of regulation regarding product and / or service information is honesty. As stipulated in the SE OJK, Financial Service Business Actors (PUJK) are required to provide and / or convey information about honest products and / or services based on actual information about the benefits, costs, and risks of each product and / or service. The word honest implies that nothing is covered up by the informer, meaning that the informer must not deliberately make ambiguities or use language that the interlocutor does not understand.
The Funding Officer (FO) is an officer who collects these funds. Through various tricks, an FO tries to provide clear information and persuasion. However, this matter of clarity becomes so subjective because sometimes it is related to cross cultures or cultural differences between the person providing the information and the recipient of the information.

One of the cultural elements frequently used in banking communication is of course language. According to Gorys Keraf [2], that language is a means of communication between members of the community in the form of sound symbols produced by human speech tools. Hamdan, Yusuf; Ratnasari, Anne; Hirzi, bold according to Urban, where the choice of words about diction in verbal messages has an important role in achieving successful negotiations process. a person often does not realize the effect of the words he uses, these words have an impact on both others and oneself, it means the number of words he used has influence.

Language is, in principle, a communication tool that always appears and is needed if at least two people speak the same language [3] but in reality, people who have different cultural backgrounds try harder to understand the language against communication in the negotiation process. The choice of language seems to be able to determine the negotiation process.

"The choice of the language (or languages) of communication is constantly subject to negotiation, and the outcome of these negotiations is usually determinant in the way meaning is locally produced and interpreted by participants [4].

But what happens if a negotiator meets an opponent who has cultural differences, for example, language. Of course, negotiation here is no longer about choosing diction, but at the stage to be able to understand the meaning of the interlocutor and even the negotiator must also practice the language applied by the interlocutor. Due to differences in cultural backgrounds, it causes misunderstandings. So to narrow or reduce language misunderstandings, competence in speaking a foreign language, or understanding more than one language is required.

"Multilingual competence needs to be regarded as being a social construct, fluctuating and chameleonic in nature and 
situated within a communicative framework that both gives shape and is constantly reshaped by it." [4].

This multilingual competence seems to be important for an FO when it is often encountered where FOs who are not even from the same culture try to use regional languages to their customers. Given that not everyone works in their respective regions, including banking FOs at Bank BTN in the Bandung area.

Bandung is a city whose people are originally Sundanese, so most people speak the Sundanese language or dialect. Sundanese language itself has quite a lot in common with Indonesian. When an FO who does not have a Sundanese cultural background enters Sundanese language into his vocabulary choices, of course, there is a motive that triggers this to happen. Especially when the negotiation process is a formal process in banking relations. With the effort to include elements of Sundanese language culture into negotiations with opponents with local culture, namely Sundanese culture in the city of Bandung, the negotiation process becomes more fluid. Of course, an FO will previously carry out the process of exploring the background of his negotiating opponent through questioning or listening.

"Listening is an interactive process. This needs to be supported by the use of body language, for example by leaning forward, tilting the head as a sign that someone is paying attention, asking questions, or giving feedback, focusing on what is being said, not on how he is saying it, increasing understanding of what is being said. discussed by taking notes immediately after the talks started. " [5].

The use of Sundanese language begins to occur at the beginning of a conversation through greetings or words of gratitude, or only in the form of affixes. It seems that the FO is consciously trying to do this considering that Sundanese is a foreign language for them. FOs often use the Sundanese regional language even though they are not Sundanese, for example in the greeting sentence at the beginning of the negotiation process "Mr. / Mrs. damang?" or small talk or behind the negotiation meeting with thanks but in the Sundanese language "hatur nuhun".

The phenomenon of using regional languages in the negotiation process actually does not only occur in the banking world and does not only occur in the city of Bandung but also, in other negotiation processes in any region, especially in areas where cultural elements are still strong. Seeing the increasingly competitive world of banking, it is possible that the use of regional languages can be used in an emotional tribal approach. This kind of phenomenon seems to be familiar in our social life where the Indonesian nation consists of more than 1,300 ethnic groups. With population movements such as transmigration, urbanization, and others, there is often a process of acculturation which is usually preceded by a process of adaptation. This adaptation was done by the newcomers to benefit.
"Ellingsworth in Arlina suggests that the process of intercultural communication is also centered on adaptation. When a situation seems favorable or supportive of one of the parties, the disadvantaged party will show more adaptive behavior" [6].

In terms of negotiations carried out by the FO, the party that is called the disadvantaged party is the FO itself because of course it will position itself as the seller of the savings product As we often hear about the proverb the buyer is king. Likewise with customers, often position themselves as kings. For this reason, an FO needs to have the ability to adapt which is called mindfulness. Iqbal in the Journal of Prophetic Sciences [6] states that mindfulness can be defined as a person's ability to adapt to a culture that is still foreign to him.

So it tickles the researcher whether it is an attempt to achieve a harmonious relationship in negotiations? Or is it the desire to seek attention and gain emotional tribal closeness? Why do they do it? Are there any effects that the FO hopes for? So it is necessary to understand from the point of view of the $\mathrm{FO}$ in this matter.

Seeing that this phenomenon is often overlooked or goes unnoticed, but actually has positive values, it is important to use it as research material so that later it can become a reference in the banking sector in managing funding to overcome the increasingly strong competition in the banking market.

"The banking sector is extremely competitive nowadays and hence oriented to the research of customer needs and wants. It is an indisputable fact that banks offer a large number of various services in the market and that these services are very similar in their essence." [7].

For this reason, this research is important to do, even because it is still very rare to research the use of language in negotiations, especially in Indonesia, especially the use of regional languages. So, the authors can say that this is the first research in Indonesia regarding the meaning of regional languages in the negotiation process.

\section{RESEARCH METHODS}

The methodology used in this research is a qualitative method with a phenomenological study approach. The main focus of the phenomenon that occurred was the use of the Sundanese language in the banking business negotiation process for FOs at Bank BTN. Phenomenology focuses on personal experiences, including how individuals experience each other [8]. The data source is divided into two, namely primary data and secondary data. Primary data comes from field results or data from observations and interviews. Meanwhile, secondary data sources are data from literature studies or literature related to this research. Completeness of data is also obtained using other techniques, such as participant observation, document search and others. 


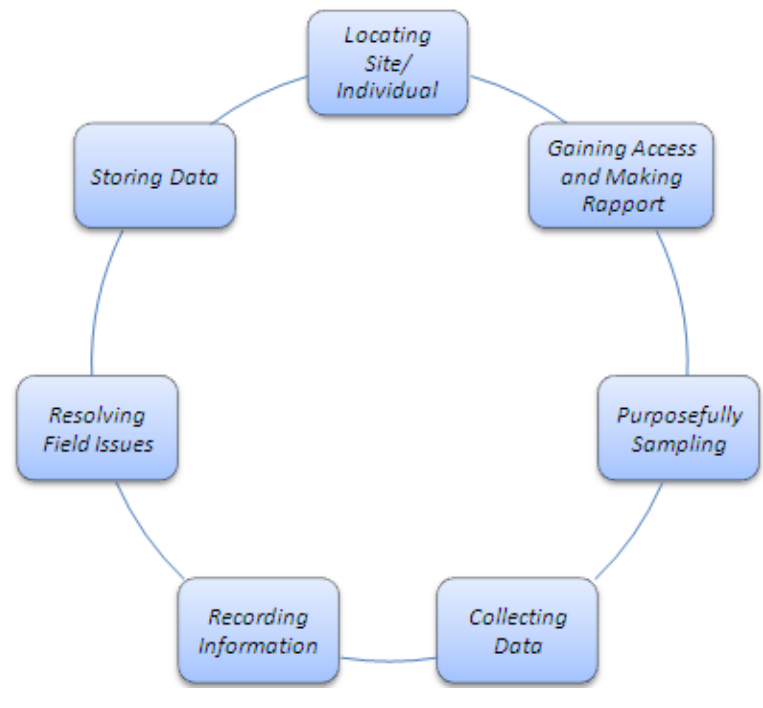

Fig. 1. A Data Collecting Circle.

Source: Creswell in Kuswarno [9].

Starting with determining the location (figure 1), the approach process, selecting informants, then collecting data through interviews, observation, documentation and literature, all the information obtained is then recorded. After a lot of information is obtained, problem solutions will appear. Then all the data to be stored and analyzed.

In the initial stage of analyzing, the researcher fully describes the phenomena experienced by the research subject. All recordings of in-depth interviews with research subjects were transcribed into written language. Furthermore, from the results of the transcription, the researcher made an inventory of important statements that are relevant to the topic. At this stage, the researcher must be patient to postpone the assessment (bracketing / epoche) so that the element of the researcher's subjectivity changes the important points in the research data obtained from the results of data collection.

Next, enter the Cluster of the meaning stage, where the researcher classifies the statements into themes or meaning units, and sets aside overlapping or repetitive statements. At this stage,: 1. Textural description (textural description): The researcher writes what is experienced, namely a description of what is experienced by the individual; 2 . Structural description (structural description): The author writes how the phenomenon is experienced by individuals. Researchers also look for all possible meanings based on the researchers' own reflections, in the form of opinions, judgments, feelings, expectations of research subjects about the phenomena they are experiencing [10].

\section{RESULTS AND DISCUSSION}

Field activities for this research were carried out in various ways as previously mentioned, one of which was interviews. The results show that at the time of the interview, all informants were in good condition, healthy and aware so that they were able to tell the experiences they had experienced during their time as FO. This also concerns the meaning and motive of using Sundanese in the banking negotiation process.

Two things make the FO use Sundanese when negotiating with his customers:

- That they want to appear more flexible, more intimate so they hope to touch the emotional side of their customers.

- Talking about or joining in unconsciously even though they don't know the meaning of a word or sentence in Sundanese. When using Sundanese in the negotiation process, the FO often takes the action immediately, that is, without going through the concept or deliberately constructing what will be conveyed when using that language. Regarding this, especially since they have lived in the Sundanese speaking area for more than a year, so they are familiar with Sundanese expressions

Reflecting on the previous FO, who in fact was a native of the region, made FOs who were not Sundanese feel less confident and even discouraged. However, this has become a separate motivation for them to better understand Sundanese and use able it well. With the concept of learning through asking other Sundanese ethnic groups and learning from experience, it makes them feel much better.

The experience experienced by FOs is not only like successful negotiations with customers, which ends at closing the placement of funds or feelings of grief when they fail, but they are able to tell events that are considered funny when interacting with their customers, including one of which is a funny experience using language. Sunda.

FOs outside the region who have different ethnicities from their customers often think that the work they are doing is quite difficult, apart from the customers' lack of understanding of Bank BTN and the products offered, also communication problems, especially language problems where their work area is still closely related to cultural elements. So that when undergoing the negotiation process, the FO is often faced with a lack of understanding of what the customer himself is conveying if the customer speaks in the local language, causing misunderstandings that can start from ambiguity. The use of appropriate language is needed so as not to cause miscommunication that starts from ambiguous language.

"The ambiguity of language mainly refers to the fuzziness caused by individual differences and the ambiguity of comprehension, and the ambiguity of the function of language. Vague language as a flexible language, refers to a special language with the extension of uncertainty and uncertain connotation. Compared with the precise language, vague language has greater generality and flexibility [11].

For this reason, the FO tries to use Sundanese at least by understanding Sundanese in carrying out the negotiation 
process. A small example is inserting the local language during the negotiation process.

Sentences or words that are considered easy, which are most often used, such as greetings, excuse me and thank you. Examples of greeting sentences used are for example "Mr / Mrs kumaha damang?". This sentence is common to start a meeting when negotiations will be held. The sentence excuses me in Sundanese which is very often used is "punten", "mangga".

Not only must understand the meaning of words, but also in understanding Sundanese we must be able to interpret the content of a sentence. Because in Sundanese there are many affixes whose placement is not standard. For example, when a funding person asks a customer to transfer funds owned by a customer to another bank. "Pretentious sir, transferred to savings from BTN keun" means that in general, asking a father (customer) to transfer his existing savings in another bank to Bank BTN. In the sentence there is the phrase "to be converted into savingsana". There are various types of vowel pronunciations (phonemes), namely: a, i, u, e, o, e ${ }^{\wedge}$ and $\mathrm{eu}$. Usually people who are not Sundanese, will have difficulty pronouncing the eu vowel, this makes Sundanese customers hear it quite funny, however, it does not reduce respect.

When asked about how they felt when they saw other FOs who were not Sundanese but used Sundanese when negotiating, that all showed positive answers to this. There is a sense of amazement when other people who are not from the same tribe try to adjust to using the local language. This also motivates other FOs to do the same. FO said that on average, the effectiveness of communication in the negotiation process increased. However, this still needs to be studied further.

The use of Sundanese itself is felt to have another impact on the negotiation process, as for the impacts referred to are:

- Relationships with customers become stronger

- The atmosphere becomes more fluid

- The effectiveness of communication is increasing

The FOs really feel the positive impact of the use of Sundanese in the negotiation process, it does not mean that the use of Sundanese has no negative impact. It is exemplified when there is a misunderstanding because of using Sundanese, for example in mentioning the numbers eight and nine, which almost have the same pronunciation. The number eight in Sundanese is dalapan, and the number Nine in Sundanese is Nine. There are times when this creates confusion. Meanwhile, the numbers in banking negotiations are very sensitive because they involve the content of the negotiations themselves.

FO can feel various hopes in using the Sundanese language, especially to help better relations so that the negotiation process becomes more relaxed and less rigid. Customers themselves also have the same expectation when an FO uses Sundanese, it will create an emotional and comfortable side so that the negotiation process becomes more relaxed.

\section{CONCLUSION}

From the results of interviews, observations and other facts, it shows that There are two kinds of use of Sundanese in the banking negotiation process, namely: 1 . The concept is that the FO consciously does this in order to appear flexible, familiar so that he is able to touch the emotional side of the customer 2 . Spontaneously, when the FO just joined in to enliven the atmosphere by using the Sundanese language, but actually didn't know the meaning with certainty.

As for the impact of using Sundanese in the banking negotiation process, are: 1. Relationships with customers become stronger 2 . The atmosphere becomes more fluid 3 . The effectiveness of communication is increasing The use of Sundanese is deemed necessary in the banking negotiation process which has a very strong working area with customs. This helps an FO to better understand the needs of his customers, not just touching his emotional side. From the involvement of the two parties in the negotiation process involving the use of Sundanese, there is a belief that when someone understands the culture of the other person, the communication between the two will become clearer.

It is hoped that FO will continue to learn Sundanese in order to better understand the needs and desires of customers, and to avoid misunderstandings caused by the ambiguity of the Sundanese language itself.

\section{REFERENCES}

[1] R. Indonesia, Surat Edaran Otoritas Jasa Keuangan Nomor 12/Seojk.07/2014 Tentang Penyampaian Informasi Dalam Rangka Pemasaran Produk Dan/Atau Layanan Jasa Keuangan. 2014.

[2] G. Keraf, Komposisi. Jakarta: Ikrar Mandiri Abadi. Hal 1. 1997.

[3] S.W. Riyanto, "Pemertahanan Bahasa Sunda Oleh Mahasiswa (Language Maintenance By Students”. Metalingua. Kemdikbud, 14(2), 243-252. 2016.

[4] S. Bono, Mariana and Melo, "Language negotiation in multilingual learning environments," Sagepub. Interntional J. Biling., vol. 5, no. 3, pp. 291-309, 2010.

[5] Y. Hamdan, "Kepribadian Negosiator". MEDIATOR, 8(56), 151-156 2005.

[6] F. Iqbal, "Komunikasi dalam Adaptasi Budaya( Studi Deskriptif pada Mahasiswa Fakultas Ilmu Sosial dan Humaniora UIN Sunan Kalijaga Yogyakarta)". Jurnal Komunikasi Profetik, 7(2), 65-76. 2014.

[7] D. K. Pavlović and E. Ruzicb, "Negotiation and Sources of Negotiation Power: Their Role and Importance in the Exchange Process in the Corporate Banking Market,” Econ. Res. Istraživanja, vol. 26, no. 1, pp. 115-138, Jan. 2013

[8] Lilltlejohn \& Foss, Teori Komunikasi. Jakarta: Salemba Humanika Hal. 458. 2014.

[9] E. Kuswarno, "Tradisi Fenomenologi Pada Penelitian Komunikasi Kualitatif Sebuah Pedoman Penelitian dari Pengalaman Penelitian". Sosiohumaniora, Vol. 9, No. 2, Juli 2007: 161-176. 2007.

[10] O. Hasbiansyah, "Pendekatan Fenomenologi: Pengantar Praktik Penelitian dalam Ilmu Sosial dan Komunikasi”. MEDIATOR, 9(56), 163-180. 2005.

[11] J. Zhang and Y. Shi, "The Application of Vague Language in International Business Negotiations from a Cross-cultural Perspective," Acad. Publ., vol. 7, no. 7, pp. 585-589, 2017. 